\title{
Representation and misrepresentation: San regional advocacy and the Global imagery
}

\section{Michael Francis and Suzanne Francis}

\begin{abstract}
The San of southern Africa are one of the most represented peoples of southern Africa. Internationally, they are most often depicted as a hunting-gathering people or as a people recently removed from that way of life. Organisations such as Survival International draw on these images for political advocacy and in campaigns for land rights for indigenous peoples. In southern Africa, San organisations fight for similar rights and, despite their membership being comprised of San people, the images and ideas of San-ness are dominated by the global imagery. The images and ideas of the San draw on racialised caricatures and colonial imagery that freeze San imagery into a mythologised past. We argue that this is a limiting factor in political advocacy that constrains the types of responses possible for aboriginal rights in Africa.
\end{abstract}

Keywords: Bushmen, cultural studies, indigenous communities, representation, San, SASI, Survival International

\section{Introduction}

The San are one of the best-known and most studied peoples of southern Africa, despite a small overall population.3 Alongside the vast corpus of academic work is a veritable industry of imaging and representation that has been created around peoples of San descent (see Ruby 1993). They have appeared in numerous films, 
TV shows and advertisements, and continue to be a common feature in the ongoing ethnic representation of southern Africa for tourism, in documentary films, academic studies and political advocacy. While this culture industry often echoes racist stereotypes of the past (see Skotnes 1996), these essentialised images feed into political advocacy and the ongoing political representation 4 of the San by some advocacy groups (Sylvain 2005). In our article we examine different levels of this political representation of the San of southern Africa. Issues of representation of the San in the tourism industry and popular culture are worthy of their own topics of research and, despite overlapping imagery and related themes, this is not a discourse that we explore in this article. Rather, we challenge the continued static image of San culture in political advocacy by engaging in debates of how the San are represented at local, national and international levels. We argue that the form of racialised representation that includes crude hunter-gatherer stereotypes is a limiting factor in political advocacy. Advocacy for the San is limited by restricting them to development rights, in accordance with these racialised hunter-gatherer images and ideas.

This article discusses but a few of the national and regional organisations that represent the San in southern Africa. We focus on a few advocacy groups that serve as examples of varying discourses pertaining to people of San descent. A much broader look at all San organisations is beyond the scope of this article. We do not discuss the internal workings of any organisation and our focus is on public imagery, as used by four organisations, to speak on behalf of and about the San in certain cases. The organisations that we discuss are the South African San Institute (SASI), the Working Group on Indigenous Minorities in Southern Africa (WIMSA), the South African San Council (SASC) and the international NGO Survival International. The local advocacy groups are largely comprised of selfdefined San people who seek to lobby respective governments on issues of rights, development and access to resources. Survival International is engaged in political advocacy in the Central Kalahari Game Reserve on a singular issue of land rights for a specific group of San. The NGO is discussed due to its vocal international media campaign, and its significance to our discussion is in what the organisation represents in terms of global reception and representation of San 'ethnic' imagery. Survival International serves as an example of an international lobby group that uses racially/ethnically based advocacy.

Globally, San politics echoes global aboriginal discourses and struggles, and may be seen to fall under general and generic terms that relate to all indigenous peoples under the mandate of the institution of the United Nations (UN). The UN has established broad definitions within which it set a mandate for indigenous peoples and projects. It seeks to create a set of global standards and ideals under which aboriginal and indigenous rights are framed. National and regional advocacy 
organisations also draw on UN standards and ideals. The definition of aboriginal, according to the United Nations Working Group on Indigenous Populations, is:

Indigenous communities, peoples and nations are those which, having historical continuity with pre-invasion and pre-colonial societies that developed on their territories, consider themselves distinct from other sectors of society now prevailing in those societies, or part of them. They form at present non-dominant sectors of society and are determined to preserve, develop and transmit to future generations their ancestral territories, and their ethnic identity, as the basis of their continued existence as peoples in accordance to their own cultural patterns, social institutions and legal systems. (United Nations 2004: 5)

In southern Africa the term 'indigenous' is most often used to refer to the black majority, excluding people of European or Asian descent (Crawhall 1999: 1). As a result there is a dual meaning of indigenous, in which the second meaning is generally used 'to identify non-dominant groups of aboriginal of prior descent with distinct territorial and cultural identities. [In Africa,] most of these groups are pastoralists or hunter-gatherers, such as the Pygmies, Hadzabe, Maasai and Tuareg' (ibid.). The broader concept of 'black' as indigenous thus has the potential to undermine San politics or mask local prejudices and discrimination of San (see Sylvain 2005 on local prejudices).

In advocacy, the San are most often represented as marginalised, powerless and exploited peoples and in many ways are in a subaltern position (see Bregin \& Kruiper 2004; Gordon 1992; Saugestad 2001; Skotnes 1996). This correlates with UN definitions that set apart indigenous communities as occupying a position of non-dominance and as victims of the dominance of other groups, including 'black' southern Africans. In advocacy, this is inexorably linked to their aboriginal status. Survival International, for example, collapses issues of marginalisation with claims of ethnicity. The San of Botswana are living as a poor, marginalised minority due to a lack of resources, reliance on the state for food aid, and a much changed social structure. In KD1 in the Kgalagadi region of Botswana, the San live mainly by regular food and water deliveries handed out by the state. Their poverty is shared by their Bantu neighbours and their marginalisation is not a direct result of their ethnicity (Pers. obs. 1).

We argue that essentialised forms of political advocacy constitute a misrepresentation of the San and assist in the maintenance of their position as a marginalised group. They are continually depicted as incapable of maintaining a rich and meaningful life, due to the loss of their idealised hunter-gatherer 'culture' instead of their socio-economic position. Survival International's campaign advocates a return to their ancestral land in order to continue their culture of hunting-gathering (http://www.survival-international.org/tribes/bushmen/). This idealisation of a 
hunting-gathering way of life structures the type of political advocacy and the form of socio-economic development called for by advocacy organisations. The San are marked as exceptional and essentially different from the communities around them, but of which they are also a part (see M. Francis 2009b).

The representation of aboriginal peoples as essentially different from the dominant groups within society is a common theme in advocacy. Aboriginal voices are used to depict an image of difference or separateness from other communities (Hitchcock 2002). Ironically this creates - for dominant groups that refuse to recognise ethnic difference - a way in which to deny their legitimacy (as in Botswana over land rights/land use). In southern Africa claims for socio-economic development based on ethnic identity, and corresponding human rights violations based on ethnic claims, have a long history. In South Africa, apartheid was based on enforced separation and hierarchical ordering of state-defined ethnic identity. In Malawi, under Kamuzu Banda, the dominant ethnically defined Chewa communities were promoted over and above the ethnically defined Yao and Tumbuka (Vail \& White 1989). The question is whether making ethnic claims to difference and to rights, based on difference, can lead to anything other than the further enforced marginalisation of one marginalised community over another. Such a question needs answering, but is beyond the scope of this article. This article does, however, begin to fracture discourses that force selfdefined San communities and peoples with San ancestry to make ethnic claims to difference based on racially defined imagery.

The concept of culture becomes essentialised and frozen, which suggests that change must be fought against and stopped. The political representation of the San, that promotes the San as archetypal victims recently divorced from a hunting-gathering way of life, structures advocacy as a return to that way of life and as the preservation of the last vestiges of this life, as a necessity and basis of all advocacy (see discussion below on Survival International). There are a variety of reasons for ethnically structured discourse, and in many ways it is simply because it is a powerful discourse for mobilising support at global and national levels. Most descriptions of the San - and especially the way in which the San are seen to articulate with the global system - are as an underclass, marginalised and excluded from an active role in shaping society (Sylvain 2005). The debate is then not whether the San are marginalised, but rather what the solution is to addressing their marginalisation. A key issue is the form of representation carried out by advocacy organisations. This consists of ethnic claims to socio-economic rights defined for rather than representing concerns of indigenous communities. This then dictates the type of advocacy proposed, as well as the proposed outcomes and solutions. Exclusivity of rights based on ancestral ethnic claims is often counterpoised against general human rights, even though these are not mutually exclusive claims - nor do they need to be. Ethnic claims to difference then become the basis for rights to land, 
political representation or socio-economic development. Instead of socio-economic class, economic poverty and political marginalisation forming the basis of claims to socio-economic development and political representation, advocacy for San people takes the form of ethnic identity and ancestral indigenous rights. As a consequence of the promotion of exclusive rights that separate the San from other communities, the solutions structure further marginalisation. The San must be and live according to primordial descriptions of ethnic identity, in order to validate the claims of advocacy organisations. Ironically, this situation would redefine their ordinary sovereign rights as 'special rights', thus having the potential to be delegitimised as undemocratic.

\section{Survival International}

Survival International is a European-based charity that 'campaigns on behalf of indigenous and Tribal peoples' (www.survival-international.org). It defines 'Tribal Peoples' as follows:

People who have lived in tribal societies for many generations. They are usually the original inhabitants of the places they live in, or at least they and their ancestors have lived there for a very long time. They provide mainly for themselves, living off the land by hunting, fishing, gathering or growing vegetables, or keeping animals. They are usually 'minorities'; fewer than the non-tribal peoples living in the area.

This definition could be used to describe many African communities in southern Africa, but it excludes Bantu-speaking peoples as non-aboriginal; referred to as invaders into 'Bushman' land by Survival International. In their online representation of San communities the NGO claims that one of the problems faced by the 'Bushmen' is that 'their homeland was invaded by cattle-herding Bantus tribes from around 1500 years ago ...' '. What is actually meant by 'tribal' is unclear, and Survival International further distinguishes between aboriginal and tribal in that "... "indigenous peoples" are all the original inhabitants of a country, but "Tribal" [peoples] are only those who live in distinct tribal societies' (www.survival-international.org). In southern Africa, such a distinction cannot be made with any great clarity without regressing to crude ethnic divisions. Such a division is unpalatable due to South Africa's recent apartheid history, which classified all peoples by state-defined racial categories and further classified black South Africans by state-defined ethnic categories, as well as the vague but racist notions behind the concept 'tribal' - non-Western/European.6

Survival International possesses an international profile for its representation of aboriginal peoples in Africa, and is a vocal supporter of a group of 'Bushmen' evicted from the Central Kalahari Game Reserve (CKGR) in Botswana. Survival International argues that mining rights trumped aboriginal rights to their ancestral land (Corry 2003). The NGO's campaign, focusing on the exclusivity of San rights, 
enabled the evicted San to return to the CKGR (December 2006, http://www.survivalinternational.org/news) with a court case settled in favour of the San. However, the merits of these arguments are contested, also by San organisations themselves.7

First, the policy of the Botswana government towards aboriginal peoples may also be seen as one of coercive modernisation, in which remote communities are relocated to settlements in order for them to obtain state resources. The Remote Area Dweller Programme (RADP) was established as a welfare programme for poverty-stricken communities in remote areas, and was funded by the Norwegian Agency for Development Cooperation, NORAD, from 1989-1996 (Saugestad 2001). The stipulated criteria for inclusion in the programmes are geographic distance from existing social services as well as economic marginalisation, rather than ethnicity (Maribe 2003; Saugestad 2001). The main goal of the RADP is to promote 'social, political, economic and cultural development of Remote Area Dweller Communities, to enable them to benefit from the economic growth of the country' (Maribe 2003: 4). The policy requires that communities comprise a minimum of 250 people and reside a minimum of $15 \mathrm{~km}$ away from an existing village or settlement. Such communities qualify for recognition as a Remote Area Dweller Settlement. Those residing in settlements of fewer than 250 people are persuaded and encouraged to relocate to or come together with others to form larger settlements, to facilitate the provision of services by the most efficient economic means (Maribe 2003: 4). So, whereas the coercive form of modernisation for access to services and the legality of the translocations do need to be addressed, the claims of mining rewards trumping ethnic rights add a completely new and unrelated discourse to that of socio-economic needs and rights.

Second, Survival International uses ethnic boundaries as absolutes between the 'Bushmen' and the 'Bantu', whereby the Bantu are seen as 'foreign invaders' in Bushman land (www.survival-international.org). The 'Bushmen' are recognised as marginalised and excluded from the reserve, but the Bakalagadi (a minority Bantu group) are not recognised as oppressed (Maribe 2003). While Maribe justifies the resettlement of the Basarwa people in Botswana on behalf of the state, he points out that the Bakalagadi people and the Basarwa have been living together as intertwined communities for a long time, and both constitute an impoverished rural underclass (2004: 3). In the remote setting of the Southern Kalahari KD1 district, peoples of San, Bakgalagadi and Basawara descent live in an intertwined and interdependent nature (Pers. obs. 1). We contend that the separation of poor peoples into neat categories limits the potential impact of land claims and substantive political representation to the benefit of a very small minority, and denies potentially 1500 to 2000 years of interaction with Bantu groups, based on archaeological findings. The archaeological record shows Iron-age furnaces starting to appear around 2000 years ago, and they are seen as a marker of Bantu-speaking people moving into the region (Dutton 1970; 
Smith 1992). Moreover, working with remote communities in Botswana as well as San communities in South Africa shows the interconnectedness of all these peoples as well as commonalities (Francis 2007, 2009b). The neat separation of peoples that Survival International fights for pits poor communities against one another. Their campaigns draw on crude caricatures of aboriginal peoples that must live 'tribally' in order for their claims to be worthwhile. This definition is loaded with prejudice, even if it is defined as positive within their discourse.

In southern Africa, more inclusive definitions that include neighbouring peoples could be used to mobilise people around mutual issues of poverty and marginalisation. Land claims and political advocacy could be more successful and have more salient gains without being exclusive (see also Le Fleur 2004 for a similar argument): they would potentially be more acceptable to the broader indigenous or black African population and other communities all too sensitive (and rightly so) to the apartheid-era separation of people based solely on externally imposed ethnicities and crude racialisation (Posal 2000). Michael Burawoy argues for political struggles that include 'local struggles, of disparate kinds, connected across national boundaries in a simultaneous War of Position and War of Movement' (2003: 251). While he is arguing for a socialist struggle on an international basis to resist the dehumanising forces of global capital, the tenets remain true, as do the causes (cf. Tomaselli 2007). This is even more certain from the perspective of the creation of the 'Bushmen' as a sub-class due to the colonial political economy of Imperial Capitalism (Wilmsen

\& Denbow 1990). While there is no disagreement on the fact that the 'Bushmen' were removed from the CKGR, the reasons behind the move are widely debated (Corry 2003; Mikalsen 2008; Suzman 2003). Without approving of Botswana's coercive actions towards the San, Mikelson started with an antagonistic relationship towards Botswana's policy, but shifted his stance when he realised that rights based on ethnicity are untenable in southern Africa. Thus, the issues of aboriginal rights and how aboriginal people are represented are germane to an understanding of the discourses the San, in general, are caught up in, and that further shape their marginalisation. The real tension is whether the San need to be seen as an ethnic minority or merely descendents of a formerly free and selfgoverning people occupying specific territory. In southern Africa, the former is untenable and the latter workable within existing state laws and institutions.

\section{San organisations of southern Africa}

SASI, WIMSA and SASC comprise three San institutions that lobby governments on behalf of the greater San population of southern Africa, mainly in Namibia, Botswana and South Africa.8 They have been instrumental in land claims, poverty alleviation and development among various San communities. SASI only works in 
South Africa, although it operates in conjunction with WIMSA. SASI and WIMSA tend to be the public political authorities authorised to speak for the San of South Africa. In an apparent conflict over who represents the San, WIMSA released this statement to the press:

We, the San of Southern Africa welcome international assistance with raising awareness about human rights abuses. We appreciate that Survival International (SI) regards it as their duty to campaign about human rights violations by the Botswana government against the San of the Central Kalahari Game Reserve (CKGR) ... However, we object strongly to the fact that Survival International seeks to give the impression that they speak on behalf of all 'the Kalahari Bushmen' when they handpick quotes from a few San only. (WIMSA 2005: 1)

The distancing of the San organisations from Survival International's campaign is due to a variety of factors beyond the immediate issue of relocations in the CKGR. The main contention is who has the right to speak for the San and what the form of that representation should comprise. This speaks immediately to contested forms of representation - including whether advocacy groups with significant power have the right to speak on behalf of, rather than to represent the often complex concerns of, communities. On the one hand, Survival International claims special rights on behalf of the San due to claims of exclusive ethnic identity. On the other hand, SASI has fought, and continues to fight, for rights for the San peoples, but does so under existing laws and agreements, rather than through ethnic claims to exclusivity. SASI recently championed land rights for the $\neq$ Khomani San of South Africa under 'the legal framework provided by the Constitution [of South Africa]' (Chennells 2002). Survival International draws on the International Labour Organisation (ILO) Convention 169 (1989) that would recognise land rights based on ethnicity and ancestral claims. This is inappropriate for southern Africa, due to the human rights violations of the recent past - including the policies of the racialised South African state that assigned people in South Africa and Namibia to ethnically defined homelands based on an apartheid categorisation of their racially and ethnically defined ancestry. In South Africa, the apartheid-era process of categorising and controlling the movement of peoples extended and imposed ethnic identities that persist despite the removal of the legal category of 'coloured' with the end of apartheid, although now subsumed under the category 'black' (Le Fleur 2004). Claims are made to territories based on the prior use and occupation of land, and not on a notion of primordial aboriginal rights. The argument used by Survival International, as well as ILO Convention 169, is wildly inappropriate for Africa and generally unnecessary, as ancestral claims to regions are not contested based on the ethnicity of claimants.

It is within this framework of racialised imagery that both Survival International and SASI work, and in so doing draw on crude racial caricatures and use similar 
imagery in their campaigns that define and bind San identity. SASI openly refers to racial stereotypes (short of stature, etc) to describe San descendents of the Drakensberg (SASI 2002). Yet, in southern Africa the rejection of externally imposed categories points to the heart of the difficulties experienced by aboriginal peoples across southern Africa. Many peoples have been stripped of their past and self-created identities through segregation, and forced incorporation into broad categories such as 'black', 'coloured', Indian and even 'white'. The Northern Cape coloured community traces its genealogy back to Khoi pastoralists, other aboriginal peoples, and a mix of colonial peoples (Elbourne 2000; Le Fleur 2004). As a marginalised segment of the historic population they were not allowed to draw on their European heritage, and at the same time were denied their aboriginal past (see Le Fleur 2004). The Constitution of the Republic of South Africa recognises the right to the expression of difference and has provisions for the legitimisation of tribal authority and traditional law within limits to preclude special rights based on ethnicity (Constitution 1996: Chapter 12). Land claims that have been won in South Africa are not based on an ethnic connection to the land, but due to laws drafted to mitigate violent dispossession and disempowerment created by colonialism and apartheid (see RSA 1994). The issues raised by Survival International's claims must be taken seriously, as violence and dispossession continue (see Tomaselli 2005: 79- 80 on the decline of hunting rights elsewhere in Botswana). Survival International's continued use of essentialised imagery of 'tribal' peoples and of cultural survival may resonate with its supporters in other parts of the world and provide an effective mobilising strategy, but its invocation of theories of cultural purity, despite all the profound changes to peoples of the region, may hinder solutions to the multitude of problems facing aboriginal communities in southern Africa (see Suzman 2003; Sylvain 2002).

\section{Strategic essentialism}

The use of strategic essentialism as a tool of political and financial mobilisation can be very effective. This is shown in the size of Survival International's membership and the resources it can mobilise through its campaigns (see www.survival-international.org). Strategic essentialism should be seen as the deployment of images of aboriginals and the use of notions of purity of these peoples and their culture as a basis for advocacy support. Survival International's website is full of imagery of aboriginals in 'traditional' dress who use 'traditional' means to survive. They even mention 'uncontacted tribes' elsewhere in the world, and depict the contemporary San as a hunting-and-gathering population being denied the right to live in such a manner. The majority of the San do not live as Survival International claims they do, and are deeply intertwined socially, culturally and politically with the larger 
communities of which they form part. The majority do not practise hunting and gathering, and those who do so are involved in other economies, straddling different but interconnected and interdependent 'worlds' (Suzman 1999; Sylvain 2002, 2003).

The political organising surrounding the San reflects much of the academic theorising about the San, whereby the San are assumed to be a homogeneous group that represents one way of life and one type of people - an archetypal aboriginal. The diversity and complexity - the contradictions, even - found on the ground amongst our interviewees in the Northern Cape, the Kalahari (South Africa and Botswana) and the Drakensberg defy monolithic representations (see Tomaselli 2005, 2007).

\section{Secret San}

In South Africa there are San descendants who live in the Drakensberg Mountains, in an area where all San are assumed to be extinct (Prins 2000, M. Francis 2009a). These Zulu-speaking San descendents use the ethnonym Abatwa as a self-designation. They have struggled for recognition as San, but have had some successes in gaining access to reserves where their ancestors left behind vibrant rock paintings (M. Francis 2009b) and access through membership of conservation boards pertaining to the use of these cultural markers (Prins 2009). The community of San descendents in the Drakensberg is a clear example of mutual ties, inter-dependency and interconnectedness within communities, as well as non-conformity to the stereotypes of aboriginality (see M. Francis 2007, 2010). These southern San are largely an assimilated group that do not fit into the stereotyped images of the Kalahari San. The Zulu-speaking San descendents, due to their 'mixed' status, can never fit into a model using strategic essentialism; they do not fit the stereotypes so powerful in the media and in political organising. The result is that they are largely excluded from political advocacy, thus denied validity as San. They have been acknowledged by SASI and tentative connections have been made with the umbrella organisations, however, the imagery used by SASI actually excludes the Abatwa people due to a crude characterisation of what it means to be San. These contradictions are played out in the ambiguities represented by the Abatwa and their demands to be recognised without recognising themselves in the images of the San.

In 2002, SASI released a report on the Abatwa people whom they refer to as the 'Secret' or 'Southern San' (SASI 2002). In the report they claim that the Southern San are "small of limb and light of skin ... [and] shunned as "Abathwa" or "small people"" (SASI 2002). The term "Abatwa' is not pejorative among Zulu-speaking San descendents. The imagery in the report actually excludes the very people being portrayed. The Abatwa do not fit the crude caricature of San according to crudely racialised imagery. They are neither ' ... small of limb and light of skin' nor are they 'short of stature' (SASI 2002). These absurd racial phenotypic expressions 
that are associated with San-ness echo apartheid or colonial notions of racial purity. Alongside the racialised discourse there circulates a powerful discourse that San people must be hunter-gatherers or must recently have been hunter-gatherers to have a recognisable claim to aboriginal identity. The image of the San as essentially hunter-gatherers confounds activism and politics, by forcing the San to comply with these stereotypes.

Steven Robbins argues that one of the biggest challenges to NGOs such as SASI was balancing between traditionalists and more Westernised 'Bushmen' (2001: 838-842). He uses the example of Petrus Vaalbooi,9 depicted as a 'Westernised' San, in conflict with the more 'traditional' Dawid Kruiper.10 SASI is seen to valorise both groups by deferring to cultural markers of clothing or language for Kruiper and supporting Vaalbooi due to his use of articulate Western discourse. The divide becomes a false tension between supposed 'modernists' and 'traditionalists', as they struggle over issues of authenticity and representation in a postmodern world. Kruiper draws upon and promotes these false distinctions of modern and traditional Bushmen as a method of seeking further access to parts of the Kgalagadi Transfrontier Park (KTP). As a traditional Bushman he, with the support of his aide,11 promotes the traditional dichotomy to the modern audience of tourists, government and advocacy groups as a method of access to greater resources. This further sets apart a very small group of Bushmen in the Northern Cape and marginalises the greater many who do not fit the 'traditional' mould. Petrus Vaalbooi also dismissed the divide in 2009 during an interview. He claimed that 'there is no distinction between traditional and Western Bushmen. Others came here and made the distinction ... because of this the understanding of our ethnicity is corrupted' (S. Francis, unpublished interview, 2009). Indeed, Vaalbooi also harmonises the dichotomy - the son of one of the last speakers of the N/u language, exacting a livelihood through subsistence farming, hoping for greater access to the KTP to fulfil his spiritual desires and serving the Bushman Council,12 a new organisation established to rival SASI (S. Francis, unpublished interview, 2009). Despite any claimed dichotomy made between Westernisers and traditionalists, none of these people 'fitted the mould of indigenous people untouched by modernity, neither were they modern citizens completely moulded by discourses of western democracy and liberal individualism' (Robbins 2001: 834). These two San leaders easily move between the traditional and modern discourses.

This split is old. Isaac Schapera pointed out as early as the late 1930s, that there is no such a thing as a 'typical Bushman' (1939: 69-72). Yet this concept haunts the field and the ideas that circulate through society, from the local to the global. For example, the Abatwa are expected to look, not like the Kalahari Bushmen, but like crude caricatures of the Kalahari Bushmen. The Kalahari Bushmen, despite not fitting one static single mould, are expected to appear according to stereotypes that they often capitulate to. If the San are seen as 'mixed', then their claims to being 
Bushmen are disqualified. This is a powerful discourse in circulation that is based on the assumption that the San are hunter-gatherers or recently were hunter-gatherers and must look the part to have a recognisable claim to aboriginal identity. This idea, based on racist imagery and the assignation of specific physical characteristics, such as skin colour, height, eye shape and so forth, both frustrates the rights-based claims of peoples who cannot fit this pattern and condemns those who do, to the further marginalisation of their lifestyle. As Kent notes, 'some anthropologists still write as if culture is genetic' (2002: 25). The political organising surrounding the San reflects much of the academic theorising whereby the San are assumed to be a homogenous group that represents one way of life and one type of people - an archetypal aboriginal. The diversity and complexity - the contradictions, even - found on the ground amongst our interviewees defy monolithic representations which are played out in the ambiguities of the Abatwa demanding to be recognised and then faltering when they are contacted by San organisations (M. Francis 2007).

The very language used to describe the 'Bushmen' or the 'San' is part of the reifying discourse that limits claims and creates non-permeable boundaries between peoples. The use of the terms 'Bushmen' or 'San' as coterminous with forager or hunter-gatherer makes an assumption that the foraging lifestyle is the central organising aspect of their existence. Any deviation from this lifestyle is viewed as a temporal anomaly or act of victimisation.

Authentic natives represent a world to which we should, apparently, wish to be returned, a world in which culture does not challenge nature. At the same time, the movement exploits the very general European belief that true citizenship is a matter of ties of blood and soil. In Europe today, this principle is used to justify antiimmigrant policies. The obverse of this, however, is the painless concession that faraway natives should be allowed to hunt in their own Bantustans. (Kuper 2003)

The warning by Kuper (2003) is not to dismiss rights-based discourses or seek redress for historic wrongs, but an appraisal of the mixing and movement of peoples across social boundaries and between economies. He points to the fact that such reified essences that are used in certain discourses dismiss real connections between peoples. People of aboriginal descent do not need to be reminded of the dangers and pitfalls of a majority speaking for a minority. Global examples abound of aboriginal rights being dismissed to make way for the rights of the non-aboriginal majority (such as currently in Botswana). The debate and its terms must be defined not in eternal essences of aboriginality, but in terms of the aboriginals as the most conspicuously marginalised peoples in southern Africa (see Suzman 2003). The boundaries of who is aboriginal and who is not must be redefined to include those who are not hunter-gatherers and have been sedentary for a considerable period of time. The discourse of exceptionalism, embodied in the political debates outlined above, is reflected in 
Kalahari dependency relationships, whereby the San have communal land rights granted. 'They want to be paid to work on the communal property, but did little to facilitate income of any kind. Thus dependency relations become a culture of entitlement - we must be paid because we are 'special' - we are the Bushmen!' (Tomaselli 2005: 59). The real-life despondency of the San is not always clearly or honestly represented in political organising. They are made to stand in as models for us all:

Hunters and nomadic herders are sometimes taken to represent not merely the first inhabitants of a country but the original human populations of the world. They are a world-wide First Nation, and theirs is the natural state of humanity. If that is so, then perhaps it follows that their rights must take precedence everywhere. However, while Upper Paleolithic hunters and gatherers operated in a world of hunters, every contemporary community of foragers or herders lives in intimate association with settled farmers. In certain cases, including the Kalahari Bushmen and the Congo Pygmies, they interacted with farming neighbours for centuries, probably for at least a millennium, before the colonial period. Exchanges with farmers and traders are crucial for their economy, and their foraging activities are geared to this broader economic context. The divide between a foraging and a farming way of life is not necessarily hard and fast. (Kuper 2003)

\section{Conclusion}

Advocacy organisations do important and necessary advocacy work. However, a critique of the discourses used in advocacy is needed, especially as some organisations apply ethnicised or racialised discourses surrounding the San as a primitive people, different from everyone else, that often borders on paternalism. The San are once again not 'our' equals and set apart as fundamentally different and incapable, forced to live as 'tribal' to qualify for the recognition of their socioeconomic rights. The discourse of the San as being different from those around them is one that is powerful and persuasive in political advocacy. Yet, one needs to reconsider this discourse and be cautious about the basis of exclusion and the socio-economic and political results of both inclusion and exclusion. Often essential claims around aboriginal identity focus on a narrow band of genealogy and appearance. To quote an example from our Kalahari research, a six-foot tall 'Bushman' is treated incredulously by some students on a fieldtrip in 2004, while a 'Bushman' who fits the caricature from 'The gods must be crazy' (Uys 1980) is assumed to be 'real' (M. Francis, pers. obs. 2). Thus, only those who fit the seemingly legitimate and valid image are then worthy of advocacy.

The implications are that political advocacy and socio-economic development interventions must not be so narrow as to construct barriers between people and create 
further injustice in society. The absolutes about who belongs and who does not must ultimately fade away as racist/nationalistic jargon, which - despite attempts to the contrary - ends up loaded with pejorative and derogatory statements that harm both the excluded and the included. New terminology and descriptions could go part of the way, but essentially what is required is a new way of conceptualising the livelihoods of the 'Bushmen' in terms of more complex socio-economic struggles. The concept of 'aboriginal' as a working term has been successfully employed for the benefit of those included in global struggles, whereby indigenous groups claim special rights and privileges based on original occupation of the land. Our critique should not be misconstrued as an argument against policies that directly benefit aboriginal peoples, rather it is one that seeks to understand why, despite successes in terms of land rights and greater state expenditures for issues concerning aboriginal peoples worldwide, they are still some of the most despondent, shattered and marginalised groups.

While the claim to substantive political representation and poverty alleviation is inherently based on racialised images of how the San 'should' live, rather than how they might choose to live or do live, their future is still defined by others. This is in contestation with more appropriate forms of advocacy that might represent the political and socio-economic concerns of the San more inclusively, rather than define for the San what those concerns and livelihoods should be. While claims to difference through ethnic representation and not social class and socio-economic rights are used as the basis of representation and advocacy, these racialised ethnic images will persist, as will a future of poverty and marginalisation, rather than poverty alleviation and citizenship.

\section{Acknowledgements}

Research for this article was conducted under the auspices of a long-term project on the San, funded by the National Research Foundation: Social Sciences, led by Keyan Tomaselli. While not ourselves NRF grant-holders, this article benefitted from the project's budget through many fieldwork trips to the Northern Cape and the Kalahari. Additional fieldwork in the Northern Cape by Suzanne Francis was funded by an Andrew Mellon Grant. Fieldwork in the Drakensberg was performed with funds provided to Michael Francis by the Wenner-Grenn Foundation for Anthropological Research. 


\section{Notes}

1 This paper was written during the period in which Michael Francis was a PostDoctoral Research Fellow in Culture, Communication and Media Studies, University of KwaZulu-Natal.

2 The authors would like to thank the two anonymous reviewers who provided valuable comments on an earlier draft of this article.

3 The population comprises approximately 110000 individuals, but it is difficult to assign an accurate number as many people are of San ancestry, but do not actively claim it or are not currently recognised as being of San descent.

4 The term 'political representation', employed in this article, draws upon and develops Hannah Pitkin's classic definition (1967). The concept is fourfold: first, the term refers to formalistic representation as the institutional and organisational arrangements through which objects and agents are represented. Second, political representation is symbolic: the meaning attached to the representative by those who are being represented. Third, descriptive (or numerical) representation includes the measure of sameness between those represented and those who represent. Finally, substantive political representation concerns what representatives do for those they claim to represent, as well as how they do it. Political advocacy is a form of substantive political representation, whether or not those who represent re-present concerns as they might apply to, or be defined by, those they claim to represent. In addition, such advocacy may include the ways in which representatives come to define the greater interests of those they represent, to make collective changes for the benefit of the represented (see also S. Francis 2009). For heuristic reasons, these frameworks have been employed simultaneously.

5 'Bantu' here refers to a broad linguistic category and is not the crude designation referred to under apartheid to mean 'black' African. In the isiZulu language, the term 'Bantu' simply means people and does not carry a negative connotation.

6 This echoes Survival International's original name of Primitive People's Fund.

7 The director, Stephen Corry, is also embroiled in a vitriolic and vocal exchange with anthropologist James Suzman on the topic of the reasons for the evictions from the CKGR (see Corry 2003:1, and the response, Suzman 2003: 4). This debate addresses issues of aboriginal rights in southern Africa that are directly relevant to post-apartheid South Africa and aboriginal peoples within the recently formed nation state.

8 There are other key organisations that work on behalf of San peoples, focusing on rights, land claims and access to resources. These include the First People of the Kalahari, the Indigenous Peoples of Africa Coordinating Committee, and non-San NGOs such as the Legal Assistance Centre in Namibia, the Botswana Centre for Human Rights (Ditshwanelo), and the Legal Resources Foundation and Chennells/Albertyn in South Africa.

9 Petrus Vaalbooi is considered to be one of the community leaders of the $\neq$ Khomani San. He is the son of Elsie Vaalbooi, who was 'discovered' in 1997 as one of less than 15 remaining speakers of the $\mathrm{N} / \mathrm{u}$ language (thought to be long extinct), was one of the signatories to the land restitution claim on behalf of the $\neq$ Khomani San and served as first Chairperson of the Communal Property Association, the organisation tasked with managing the land received through the restitution framework. 
10 Dawid Kruiper is considered to be one of the community leaders of the $\neq$ Khomani San. He is referred to as the 'Traditional Leader' by SASI. He was one of the signatories to the land restitution claim on behalf of the $\neq$ Khomani San. His father was Regopstaan Kruiper, who envisioned that land would be returned to the $\neq$ Khomani San.

11 Relative, Belinda Kruiper.

12 The Bushman Council was established in January 2009 by the $\neq$ Khomani San to represent them to the CKGR. It serves as a rival organisation to SASI.

\section{References}

Bregin, E. and B. Kruiper. 2004. Kalahari rainsong. Durban: University of KwaZulu-Natal Press.

Burawoy, M. 2003. For a sociological Marxism: the complementary convergence of Antonio Gramsci and Karl Polanyi. Politics and Society 31(2): 193-261.

Chennells, R. 2002. The Khomani San land claim. Cultural Survival Quarterly 26(1): 51-53.

Corry, S. 2003. Bushmen - the final solution and blaming the messenger. News, reactions and interactions. Before Farming 14: 1-4.

Crawhall, N. 1999. Indigenous peoples of South Africa: current trends. Project for the rights of indigenous and tribal peoples. Geneva: International Labour Office.

Dutton, T.P. 1970. Iron smelting furnace dated $630 \pm 40$ years A.D. in the Ndumu Game Reserve. Lammergeyer 12: 37-40.

Elbourne, E. 2000. Race, warfare, and religion in mid-nineteenth century Southern Africa: the Khoikhoi Rebellion against the Cape Colony and its uses, 1850-1858. Journal of African Cultural Studies 13(1): 17-42.

Francis, M. 2004. Personal observations 2: observations of the San in KD1, Botswana, July. . 2007. Explorations in ethnicity and social change among San descendents of the Drakensberg Mountains, KwaZulu-Natal. PhD Thesis, University of Natal, Durban. .2009a. Contested histories: a critique in the rock art. Visual Anthropology 22(4): 327-343. . 2009b. Silencing the past: historical and archaeological colonisation of the southern San KwaZulu-Natal, South Africa. Anthropology Southern Africa 32 (3 \& 4): 106-116. 2010. The crossing: the invention of tradition among San descendents of the Drakensberg, KwaZulu-Natal, South Africa. African Identities 8(1): 39-52.

Francis, M. and S. Francis. 2009. Personal observations 1: observations of the San in KD1, Botswana, July.

Francis, S. 2009. Gender, numbers and substance: women parliamentarians and the 'politics of presence' in KwaZulu-Natal. Transformation 70: 119-141. . 2009. Unpublished interview with Petrus Vaalbooi, Northern Cape, 26 June.

Gordon, R. 1992. The Bushman myth; the making of a Namibian underclass. Boulder, CO: Westview Press.

Hitchcock, R.K. 2002. 'We are the First People': land, natural resources, and identity in the Central Kalahari, Botswana. Journal of Southern African Studies 28(4): 797-824. 
International Labour Organization (ILO). 1989. Convention no. 169: Convention concerning Indigenous and Tribal Peoples in Independent Countries. Geneva.

Kent, S., ed. 2002. Ethnicity, hunter-gatherers, and the 'Other': association or assimilation in Africa. Washington and London: Smithsonian Institution Press.

Kuper, A. n.d. Return of the native. http://www.newhumanist.org.uk (accessed September 2003).

Le Fleur, C. 2004. The recognition of South Africa's First People in the new democratic dispensation. Paper presented at the Annual Anthropology South Africa Conference, University of the Free State, Bloemfontein.

Maribe, C.S. 2003. The relocation of the former residents of the Central Kalahari Game Reserve. Policy document. Gaborone: Ministry of Foreign Affairs and International Cooperation.

Mikalsen, O. 2008. Development communication and the paradox of choice: imposition and dictatorship in comparing Sami and San Bushmen experiences of cultural autonomy. Critical Arts 22(2): 95-332.

Pitkin, H.F. 1967. The concept of representation. Berkeley: University of California Press.

Posal, D. 2000. What's in a name? Racial categorizations under apartheid and their aftermath. Transformation 47: 50-72.

Prins, F.E. 2000. Forgotten heirs: the archaeological colonisation of the Southern San. Native title and the transformation of archaeology in the postcolonial world. Oceania Monograph 50: 138-152. . 2009. Secret San of the Drakensberg and their rock art legacy. Critical Arts 23(2): 190-208.

Republic of South Africa. 1994. Restitution of Land Rights Act [Act No. 22 of 1994]. Details? . 1996. Constitution of the Republic of South Africa [Act No.108 of 1996]. Pretoria: Government Printer.

Robbins, S. 2001. NGOs, 'Bushmen' and double vision: the $\neq$ Khomani San land claim and the cultural politics of 'community' and 'development' in the Kalahari. Journal of Southern African Studies 27(4): 833-853.

Ruby, J., ed. 1993. The cinema of John Marshall. New York: Harwood and Breach.

Saugestad, S. 2001. The inconvenient indigenous: remote area development in Botswana, donor assistance, and the First Peoples of the Kalahari. Uppsala: The Nordic Africa Institute.

Schapera, I. 1939. A survey of the Bushmen question. Race Relations 6: 8-83.

Skotnes, P., ed. 1996. Miscast: representing the San. Cape Town: University of Cape Town Press.

Smith, A. 1992. Pastoralism in Africa. London: Hurst.

South African San Institute (SASI). 2002. Annual report, December. http://www.san.org.za/ sasi/home.htm (accessed 15 September 2009). . 2002. http://www.san.org.za (accessed 20 July 2009).

Survival International. 2002. www.survival-international.org (accessed 20 July 2009).

Suzman, J. 1999. Things from the bush: a contemporary history of the Omaheke Bushmen. Basel: P. Schlettwein. 
. 2003. Response to Bushmen - the final solution and blaming the messenger. News, reactions and interactions. Before Farming 14: 4-10.

Sylvain, R. 2002. 'Land, water, and truth': San identity and global indigenism. American Anthropologist 104(4): 1074-1085.

.2003. Class, culture and recognition: San farm workers and indigenous minorities. Anthropologica 45: 111-119.

. 2005. Disorderly development: globalization and the idea of culture in the Kalahari. American Ethnologist 32(3): 354-370.

Tomaselli, K. 2005. Where global contradictions are the sharpest: research stories from the Kalahari. Amsterdam: Rozenberg Publishers.

Tomaselli, K., ed. 2007. Writing in the San/d: autoethnography among the indigenous southern Africans. Plymouth: AltaMira Press.

United Nations. 2004. The concept of indigenous peoples. New York: United Nations.

Uys, J. 1980. The gods must be crazy. Gabarone: Mimosa Films. 109 min.

Vail, L. and L. White. 1989. Tribalism in the political history of Malawi. In The creation of tribalism in Southern Africa, ed. L. Vail, 151-184. Berkeley and Oxford: University of California Press.

Wilmsen, E.N. and J.R. Denbow. 1990. Paradigmatic history of San-speaking peoples and current attempts at revision. Current Anthropology 31(5).

Working Group on Indigenous Minorities in Southern Africa (WIMSA). 2005. San from southern Africa concerned with Survival International campaign. Press release. 